\title{
The Relationship Between Social Support and Psycchological Well Being of Indonesian Rural to Urban Migrant University Students in Universitas Airlangga
}

\author{
Mahda P. Rachmadhani ${ }^{1,2}$, Listyati Setyo Palupi $\mathrm{i}^{1,2,3 *}$ \\ ${ }^{1}$ Personality and Social Psychology Department, Faculty of Psychology, Airlangga University, \\ Surabaya, Indonesia \\ ${ }^{2}$ Health and Environmental Sustainability Research Group, Faculty of Psychology, Airlangga \\ University, Surabaya, Indonesia \\ ${ }^{3}$ Addiction Study Centre, Airlangga University, Surabaya, Indonesia
}

\begin{abstract}
Indonesian parents believe that higher education in urban area or big city such as Surabaya have a good quality compared to the one in rural area. Therefore, they encourage their children to pursue higher education in Surabaya. However, it has been identified that rural to urban students has emotional disorder when trying to adapt to the urban life. This circumstances lead to a low level psychological well-being. One of the factors that could increase psychological wellbeing condition is social support. However, there is still little evident that shown the relationship between social support and psychological well-being among plural to urban students. Therefore, the aim of this study is to identified the relationship between social support and psychological well-being. This was quantitative research that used social support scale and psychological well-being scale. This research involved 226 students of Airlangga University, Surabaya. The value result of correlation coefficient is 0.018 which mean in this study there is a positive relationship between social support and psychological well-being of Airlangga University rural to urban students.
\end{abstract}

\section{Introduction}

The quality of higher education is still uneven in Indonesia, making many students decide to continue their tertiary education in big cities, it is also because students expect a good future so that many students are willing to go to college to come out of their home regions [1]. So that causes these students must migrate, then students must survive in their new environment and go through the changes and differences in life [2]. In changing aspects of life, rural to urban students may experience several problems such as culture shock that can affect their lives due to cultural differences [3]. Due to cultural differences in the area now, rural to urban students can also experience homesickness in their new environment because

* Corresponding author: listyati.palupi@psikologi.unair.ac.id 
of differences in culture, language, and customs in their new environment [4]. With the problems faced by rural to urban students, it can have a negative impact that affects their psychological well-being. The results of interviews conducted by researchers, low psychological well-being found in overseas students at Airlangga University that 3 of them were found to have low psychological well-being. According to Ryff and Keyes [5] that psychological well-being, happiness, and also the satisfaction of a person can cause factors that support and also encourage the emergence of positive functions that arise in a person.

In order to have good psychological well-being, social support also needs to be considered. According to Cohen and Syme 1985 [6] that social support is one positive factor that can help as a means of maintaining mental health. Based on the results of 1997 Friedlander's research [7] that social support confirmed that rural to urban students can cause a lack of contact and social support from family and friends. Research on the relationship of social support with psychological well-being in rural to urban students is still not widely explore specially in the context of Airlangga University therefore this research is aim to investigate the relationship between social support and psychological wellbeing of rural to urban students at Airlangga University.

\section{Method}

This research using quantitative method with associated descriptive approaches. it is located in Airlangga University Surabaya, the subjects of this search are under graduate rural to urban students. The instrument used by researchers consisted of questionnaires. The data collection technique in this study is a survey technique, while the subject taking technique uses Purposive Sampling and using Multidimensional Scale Perceived Social Support (MSPP) developed by Zimet [6] and for measured Psychological Well Being, author using Javanese Psychological Well-Being Scale developed by Palupi [8]. The analysis technique uses the correlation technique or Pearson Product Moment, a nonparametric statistical technique that assisted by IBM SPSS Statistics version 25 .

\section{Data and Results}

Table 1. Demographics Characteristics

\begin{tabular}{lcc}
\hline \multicolumn{1}{c}{ Characteristics } & $\begin{array}{c}\text { Frequency } \\
(\mathbf{N = 1 5 6 )}\end{array}$ & Percentage \\
\hline Gender & 39 & $17 \%$ \\
Male & 187 & $83 \%$ \\
Female & & \\
\hline Age & 24 & $10,4 \%$ \\
18 & 44 & $19,1 \%$ \\
19 & 47 & $20,4 \%$ \\
20 & 51 & $22,2 \%$ \\
21 & 40 & $18,7 \%$ \\
22 & 15 & $6,5 \%$ \\
23 & 5 & $2,2 \%$ \\
24 & & \\
\hline
\end{tabular}


Based on data processing, descriptively, Table 1 found that there were 226 subjects. From demographic data based on sex, it is dominated by female as many as 187 people $(80.12 \%)$ while male as many as 39 people $(17 \%)$. Based on age, subjects who were in the age range of 21 years had the highest percentage $(22.2 \%)$ or as many as 51 people. Then proceed at the age of 20 years which has a percentage of (20.4\%) while the smallest is at vulnerable age of 24 years, namely as many as 5 people or only $(2.2 \%)$.

Table 2. Descriptive Characteristics

\begin{tabular}{lcc}
\hline & Social Support(X) & Psychological well-being(Y) \\
\hline $\mathrm{N}$ & 226 & 226 \\
\hline Minimum & 42 & 21 \\
\hline Maximum & 84 & 33 \\
\hline Range & 42 & 12 \\
\hline Mean & 65,26 & 27,14 \\
\hline Standar deviasi & 9,704 & 2,369 \\
\hline Skewness & $-0,231$ & 0,304 \\
\hline Kurtosis & $-0,673$ & $-0,122$ \\
\hline
\end{tabular}

Based on the table it is known that the total number of subjects was 226 subjects. Social support has the highest value of 84 , the lowest value of 42 with a range of 42 . While the psychological well-being variable has the highest value of 33, while the lowest value of 21 , and with a range of 12 . Social support has an average value obtained that is, 62.26 with a standard deviation of 9.704 . Whereas psychological well-being has an average value of 27.14 and a standard deviation of 2.369 .

In the social support variable, a skewness value of -0.0231 is obtained, which means that the data distribution tends to the right side. While kurtosis is -0.673 which shows the distribution of spiky data. In the Psychological well-being variable, a skewness value of 0.304 is obtained, which means that the data distribution tends to the left side. while kurtosis is -0.122 which means that the data distribution tends to be flat

Table 3. Descriptive Analysis Statistic

\section{Social Support Psychological Well-Being}

\begin{tabular}{llcc}
\hline & Correlation & & \\
Social Support & Coefficient & 1 & 0,157 \\
& Sig. (2-tailed) & 226 & 0,018 \\
& N & & 226 \\
\hline Psychological & Correlation & 0,157 & 1 \\
Well-Being & Coefficient & 0,018 & \\
& Sig. (2-tailed) & 226 & 226 \\
& N & & \\
&
\end{tabular}

In the table above shows the number 0.018 . Correlation test can be said if it has a significance value of less than 0.05 . This shows that the results of hypothesis testing for the correlation of the two variables, namely social support variables and Psychological WellBeing variables have a positive relationship. 


\section{Discussion}

The significance value of the correlation test results which have a value of 0.018 , means that the results of this study shown that the there is a relationship between social support with psychological well-being in rural to urban students at Airlangga University, Surabaya. This study is in accordance with previous studies conducted by Fransisca [9] which found that there is a significant positive relationship between social support and psychological well-being of rural to urban students at the Faculty of Psychology, Soegijapranata University, Semarang. Previous research conducted by Yasin and zulkifli [10] also showed that there is a relationship between social support and psychological well-being.

The value of the relationship between the two variables is 0.157 which means that the relationship between social support and psychological well-being in rural to urban students at Airlangga University shows a weak relationship. This is due to SEVERAL other factors that could influence psychological well-being such as age, sex, social economic status factors, religiosity, personality, marriage, life experience and interpretation, cultural background and locus of control [11]. In addition, according to Rathi and Rastogi [12] other factors that can also influence the level of psychological well-being is stress. Therefore, future research should consider other factors that could influence psychological well-being beside social support.

\section{References}

[1] Harita, A. N. Interaksi Struktur dan Agency: Sudi Kasus Migrasi Pendidikan Mahasiswa Perempuan Luar Jawa ke Surabaya . Universitas Negeri Surabaya (2018)

[2] Rufaida, H., \& Kustanti, E. R. Hubungan Antara Dukungan Sosial Teman Sebaya dengan Penyesuaian Diri Pada Mahasiswa Rantau Dari Sumatera Di Universitas Diponegoro. Universitas Diponegoro (2017)

[3] Hidayah, N., \& Hendrastomo, G. Fenomena Culture Shock (Gegar Budaya) Pada Mahasiswa Perantauan Di Yogyakarta. Universitas Negeri Yogyakarta (2015)

[4] Walton, E. A., \& Thurber, C. A. Homesickness and Adjustment in University Students. Journal of American College Health (2014)

[5] Ryff, D. C., \& Keyes, L. C. The Strucutre of Psychological Well Being revisited. University of Wisconsin (1995)

[6] Zimet, G. The Multidimensional Scale of Perceived Social Support . Indiana University School of Medicine, 30-41 (1988)

[7] Tajalli , P., sobhi , A., \& Ganbaripanah, A. The relationship between daily hassles and social support on mental health of university students. Islami Azad University (2010)

[8] Palupi, L. S. Psychological Well-Being of Elderly People in Indonesia: Javanese Psychological Well-Being Perspective. Universitas Airlangga, 177-180 (2018)

[9] Fransisca, n. Hubungan Antara Dukungan Sosial Dengan Psychological Well-Being Pada Mahasiswa Perantau Di Universitas Katolik Soegijapranata Semarang. Fakultas Psikologi Universitas Katolik Soegijapranata (2018)

[10] A. S. \&. D. M. A. Yasin, "The relationship between social support and psychological problems among students," International Journal of Business and Social Science, p. 1, (2010).

[11] Negraheni, A. S., \& Pratisti, W. D. Hubungan Antara Dukungan Sosial dengan Psychological Well Being pada Guru Honorer Daerah. Universitas Muhammadiyah Surakarta (2016) 
[12] Nugroho, Y. A. Hubungan Antara Dukungan Sosial Kleuarga dengan Psychological Well-Being pada Narapidana Anak di Lapas di Klas 1 Kutoarjo. Universitas Krsiten Satya Wacana, 07 (2019) 